\title{
Volatile Components of Fermented Feedstuffs - Correcting Dry Matter and Energy Estimation
}

\section{DOI:10.31274/air.12926}

Garland Dahlke, Iowa Beef Center, Iowa State University; John Goeser, Rock River Laboratory, and University of Wisconsin-Madison

\section{Summary and Implications}

Fermented feedstuffs contain a number of volatile compounds such as organic acids, alcohols, ammonia and others that are lost in the oven dry-down process used to estimate feed dry matter. By not accounting for these components, errors in the estimation of moisture, caloric content and crude protein content of the feed will occur. This paper addresses the volatile components of major concern.

\section{Introduction}

Cost effective throughput in commercial feed testing laboratories generally includes the use of microwave or forced air drying ovens to arrive at feed dry matter values followed by the use of NIR technology to estimate feed nutrient content. In this process many of the volatile components of the sample are driven off leading one to assume these were part of the sample's moisture. The final outcome tends to skew the nutrient levels estimated, and in most cases, will lead to an underestimation of feed energy content and occasionally the crude protein estimation as well due to ammonia dissipation. For an example, the following corn silage sample which had underwent a microwave dry down followed by an NIR evaluation returned the following results when there is no correction to the dry matter or volatile compound content:

$\begin{array}{ll}\text { Dry Matter \% } & =41.13 \\ (58.87 \% \text { inferred water content } \\ \text { Cr.Protein \% } & =7.57 \text { (dry basis) } \\ \text { Ash \% } & =4.59 \text { (dry basis) } \\ \text { aNDF \% } & =34.30 \text { (dry basis) } \\ \text { Fat (EE) \% } & =2.46 \text { (dry basis) } \\ \text { NFC \% } & =51.96(\text { dry basis) } \\ \text { TDN } & =66.9 \% \\ \text { NE m } & =0.70 \mathrm{Mcal} / \mathrm{lb} \mathrm{DM} \\ \text { NE g } & =0.43 \mathrm{Mcal} / \mathrm{lb} \mathrm{DM}\end{array}$

A fermentation analysis of a paired sample of the same feed indicated that there were; $8.33 \%$ organic acids, $1.42 \%$ alcohols and $0.13 \%$ ammonia in the wet feed. When the sample was dried a large proportion of these items were evaporated away from the sample. The Nordic Feed Evaluation System does provide a guide as to what was probably lost. It does not address all of the volatile components, but an estimate of the major contributing volatile components is addressed and a truer dry matter can be calculated as such:

Corrected Dry Matter* $=$ Uncorrected Dry Matter + Lactic Acid x $(0.45-0.09 \times \mathrm{pH})+$ Acetic Acid x $(1.5-0.233 \times \mathrm{pH})$ + Proprionic Acid x (1.4 - 0.182 x pH) + Butyric Acid x (1.9 $-0.272 \times \mathrm{pH})+$ Alcohol + Ammonia $\mathrm{x} 0.6$

*if pH is 5 or greater then Lactic Acid is removed from the equation

When our original sample is corrected for the just mentioned volatile compounds the analysis of this same corn silage becomes:

$\begin{array}{ll}\text { Dry Matter \% } & =44.25 \\ (55.75 \% \text { inferred water) } & \\ \text { Cr.Protein \% } & =8.10 \text { (dry basis) } \\ \text { Ash } \% & =4.27 \text { (dry basis) } \\ \text { aNDF } \% & =31.87 \text { (dry basis) } \\ \text { Fat }(\mathrm{EE}) \% & =2.29 \text { (dry basis) } \\ \text { NFC \% } & =54.3 \text { (dry basis) } \\ \text { TDN } & =68.3 \% \\ \text { NE m } & =0.72 \text { Mcal / lb DM } \\ \text { NE g } & =0.44 \text { Mcal / lb DM }\end{array}$

The ammonia component is also factored back into the crude protein estimation as well as the dry matter at the same rate and the remaining volatiles become part of the NFC (nonfiber carbohydrate) fraction for simplicity of illustrating this phenomenon.

\section{Materials and Methods}

A database of corn silage, alfalfa haylage, grass silage and high moisture corn nutrient and fermentation values was shared by Rock River Laboratories, Watertown WI along with a minor set of in-house data that also included wet distillers grain and sweet bran to determine if there were any patterns in the nutrient profiles that would provide a tip as to what volatile components may exist in a given sample. Dry samples and those that did not undergo fermentation were

Copyright (9) 2021 by the Authors. This is an open access article published under the CC BY-NC license (https://creativecommons.org/licenses/by-nc/4.0/), which allows for non-commercial reuse with proper attribution. 
excluded from the database. An analysis of variance was conducted on the reported characteristics of these samples to determine if there were any key indicators as to what might be expected in volatile outcomes. A regression equation was then developed as a predictive model.

\section{Results and Discussion}

A summary of the data is provided in Table 1. Both uncorrected and corrected dry matter and crude protein values are also provided to illustrate the impact of the correction. Equations were developed on the corn silage, alfalfa haylage, high moisture corn and grass silage samples to model the potential volatile acids, ammonia and alcohol yield. The wet distillers and sweet bran categories did not have enough samples to build a robust model. Note that the equations $1 \mathrm{~A}, \mathrm{~B}, \mathrm{C}$ and $\mathrm{D}$ give an estimation of total acids produced for these 4 feedstuffs. Equations 2A, B, C and D look at ammonia production and Equations 3A, B, C and D attempt to describe alcohol production. Total acid production is fairly predictable since $\mathrm{pH}$ and uncorrected moisture are big drivers in this outcome and are easily measured. Estimating individual organic acids through this indirect methodology is difficult. Ammonia production is also fairly predictable in feeds containing higher crude protein. Feeds with lower crude protein are more difficult to assess, but the overall quantity and standard error of the low crude protein samples is small so an average value may suffice. Alcohol however is quite variable and is not an easy component to determine indirectly. The average alcohol concentrations are fairly significant in these feeds as would be the caloric contribution of alcohol to the energy pool for animals consuming these feeds. The use of a breathalyzer technology may be an option for rapid, low cost evaluation of alcohol content when needed.

\section{Acknowledgements}

The authors would like to thank the staff of the Iowa State University Beef Nutrition Farm and Rock River Laboratory Inc. for their assistance with this project.

Copyright (C) 2021 by the Authors. This is an open access article published under the CC BY-NC license (https://creativecommons.org/licenses/by-nc/4.0/), which allows for non-commercial reuse with proper attribution. 
Table 1. Average volatile compound concentrations in some common feedstuffs

\begin{tabular}{|c|c|c|c|c|c|c|}
\hline & Corn Silage & $\begin{array}{l}\text { Alfalfa } \\
\text { Haylage }\end{array}$ & $\begin{array}{l}\text { High Moisture } \\
\text { Corn }\end{array}$ & $\begin{array}{l}\text { Grass } \\
\text { Silage } \\
\end{array}$ & Sweet Bran & $\begin{array}{l}\text { Wet Distillers } \\
\text { Grain }\end{array}$ \\
\hline $\mathrm{n}$ & 5170 & 2944 & 607 & 1097 & 2 & 30 \\
\hline $\mathrm{pH}$ & 3.92 & 4.75 & 4.23 & 4.55 & 4.2 & 4.27 \\
\hline Ammonia $\%$ & 0.12 & 0.31 & 0.09 & 0.24 & 0.16 & 0.31 \\
\hline Alcohol\% & 1.40 & 0.79 & 0.62 & 1.16 & 1.48 & 1.94 \\
\hline Lactic\% & 4.24 & 4.06 & 1.51 & 4.53 & 12.45 & 1.87 \\
\hline Acetic $\%$ & 2.48 & 2.2 & 0.59 & 2.16 & 0.02 & 0.12 \\
\hline Butyric\% & 0.05 & 0.49 & 0.02 & 0.43 & 0 & 0.01 \\
\hline Proprionic & 0.09 & 0.12 & 0.05 & 0.11 & 0.19 & 0.02 \\
\hline \multicolumn{7}{|c|}{ Uncorrected \% } \\
\hline $\begin{array}{l}\text { Dry Matter } \\
\text { Corrected \% }\end{array}$ & 36.5 & 39.4 & 66.1 & 35.0 & 55.8 & 37.7 \\
\hline Dry Matter & 39.9 & 42.3 & 67.2 & 37.8 & 58.4 & 40.1 \\
\hline \multicolumn{7}{|c|}{ Uncorrected \% } \\
\hline $\begin{array}{l}\text { Cr. Protein } \\
\text { Corrected } \%\end{array}$ & 7.89 & 19.00 & 8.60 & 12.97 & 23.61 & 32.00 \\
\hline Cr.Protein & 8.33 & 20.44 & 8.96 & 14.40 & 23.58 & 33.04 \\
\hline
\end{tabular}

*Crude protein results expressed on a dry matter basis, all others are expressed on an as-fed basis

\section{Equation $1 \mathrm{~A}$ - Estimated volatile acid concentration in corn silage}

$\mathrm{CSa} \%=-3.24+7 \mathrm{hr} \times 0.09+\mathrm{uM} \times 0.18-\mathrm{pH} \times 2.31$

Where: $7 \mathrm{hr}=7$ hour starch digestibility

$\mathrm{uM}=$ uncorrected sample moisture

$\mathrm{R}^{2}=0.49$

$\mathrm{pH}=$ feed sample $\mathrm{pH}$

Multiple $\mathrm{R}^{2}=0.70$

StError $=1.63$

\section{Equation 1B - Estimated volatile acid concentration in alfalfa haylage}

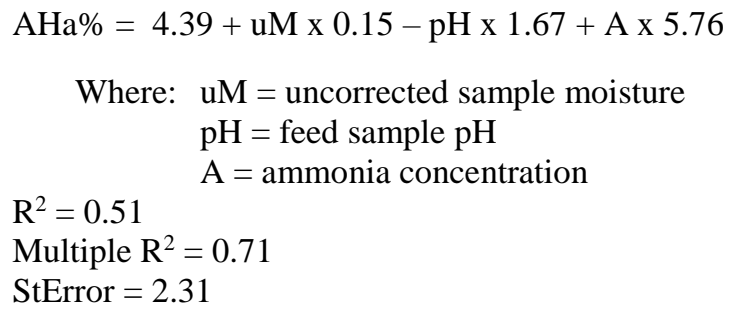

Equation 1C - Estimated volatile acid concentration in high moisture corn*

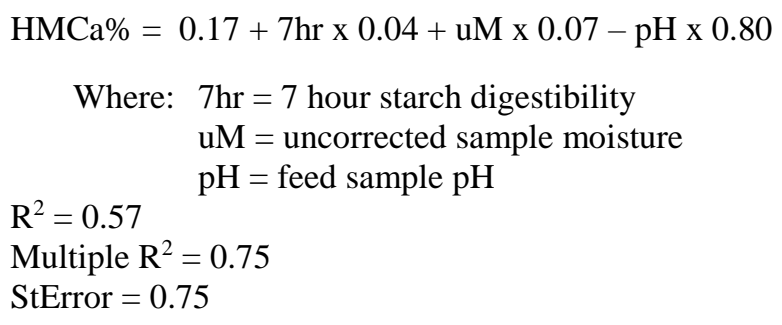

Copyright (C) 2021 by the Authors. This is an open access article published under the CC BY-NC license (https://creativecommons.org/licenses/by-nc/4.0/), which allows for non-commercial reuse with proper attribution. 
*based on samples containing at least $1 \%$ acid

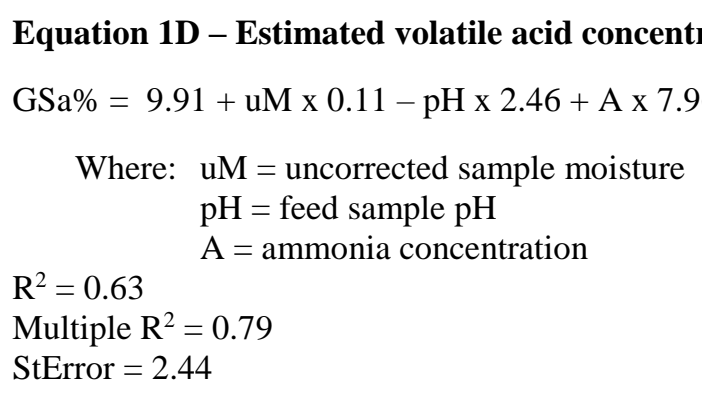

Equation $2 \mathrm{~A}$ - Estimated ammonia concentration in corn silage

$\mathrm{CSn} \%=-0.27+\mathrm{uFAT} \times 0.01+\mathrm{uLIG} \times 0.004+\mathrm{uCP} \times 0.02+7 \mathrm{hr} \times 0.003-\mathrm{uM} \times 0.0005$

Where: $\mathrm{uFAT}=$ uncorrected ether extract concentration

$\mathrm{uLIG}=$ uncorrected lignin concentration

$\mathrm{uCP}=$ uncorrected crude protein concentration

$7 \mathrm{hr}=7$ hour starch digestibility

$\mathrm{R}^{2}=0.16$

$\mathrm{uM}=$ uncorrected sample moisture

Multiple $\mathrm{R}^{2}=0.40$

StError $=0.06$

Equation 2B - Estimated ammonia concentration in alfalfa haylage

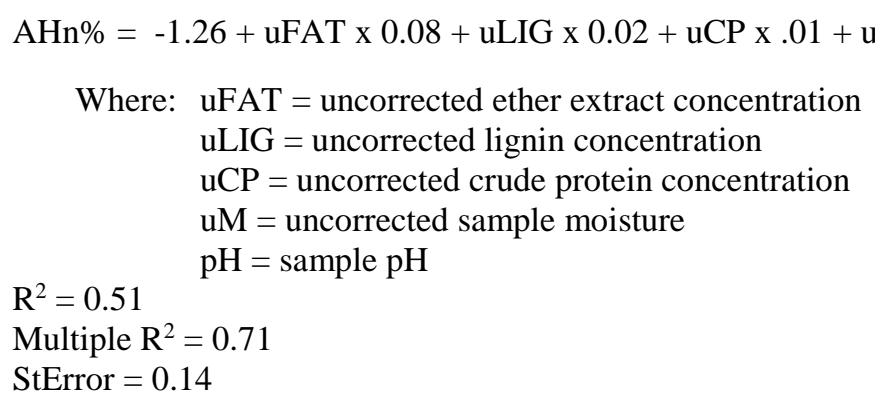

\section{Equation 2C - Estimated ammonia concentration in high moisture corn}

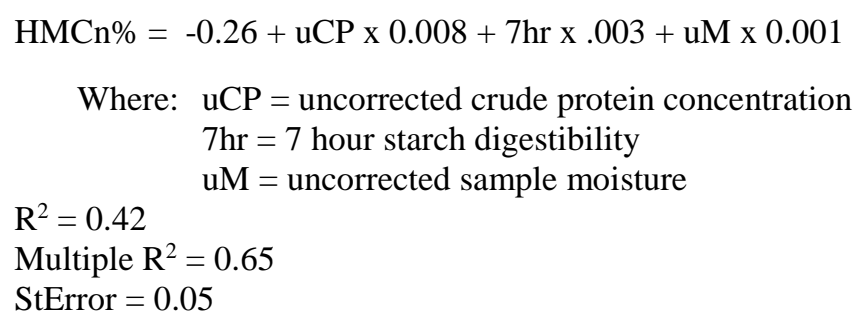

Copyright $(\odot 2021$ by the Authors. This is an open access article published under the CC BY-NC license (https://creativecommons.org/licenses/by-nc/4.0/), which allows for non-commercial reuse with proper attribution. 


\title{
Equation 2D - Estimated ammonia concentration in grass silage
}

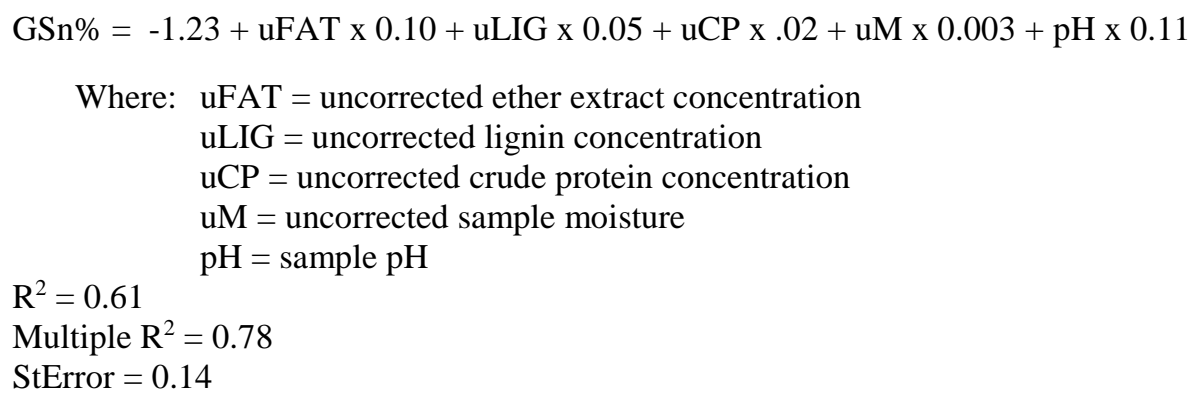

Equation 3A - Estimated alcohol concentration in corn silage

$\mathrm{CSe} \%=-1.61+\mathrm{uCP} \times 0.05+7 \mathrm{hr} \times 0.01+\mathrm{uM} \times 0.02+\mathrm{AA} \times 0.33$

Where: $\mathrm{uCP}=$ uncorrected crude protein concentration

$7 \mathrm{hr}=7$ hour starch digestibility

$\mathrm{uM}=$ uncorrected sample moisture

$\mathrm{R}^{2}=0.24$

$\mathrm{AA}=$ acetic acid concentration

Multiple $\mathrm{R}^{2}=0.49$

StError $=0.92$

\section{Equation 3B - Estimated alcohol concentration in alfalfa haylage}

$\mathrm{AHe} \%=-0.67+$ uFAT $\times 0.34-\mathrm{uCP} \times .02+\mathrm{uM} \times 0.01+\mathrm{AA} \times 0.17$

Where: $\mathrm{uFAT}=$ uncorrected ether extract concentration $\mathrm{uCP}=$ uncorrected crude protein concentration $\mathrm{uM}=$ uncorrected sample moisture

$\mathrm{R}^{2}=0.29$

AA $=$ sample acetic acid concentration

Multiple $\mathrm{R}^{2}=0.54$

StError $=0.76$

\author{
Equation 3C - Estimated alcohol concentration in high moisture corn \\ $\mathrm{HMCe} \%=-1.04+\mathrm{uCP} \times 0.08+7 \mathrm{hr} \times .01+\mathrm{AA} \times 0.53$ \\ Where: $\mathrm{uCP}=$ uncorrected crude protein concentration \\ $7 \mathrm{hr}=7$ hour starch digestibility \\ $\mathrm{AA}=$ sample acetic acid concentration \\ $\mathrm{R}^{2}=0.31$ \\ Multiple $\mathrm{R}^{2}=0.56$ \\ StError $=0.31$
}




\section{Equation 3D - Estimated alcohol concentration in grass silage}

$$
\begin{aligned}
& \mathrm{GSe} \%=0.91-\mathrm{uLIG} \times 0.08-\mathrm{uCP} \times .05+\mathrm{uM} \times 0.01+\mathrm{AA} \times 0.31 \\
& \text { Where: } \mathrm{uLIG}=\text { uncorrected lignin concentration } \\
& \mathrm{uCP}=\text { uncorrected crude protein concentration } \\
& \mathrm{uM}=\text { uncorrected sample moisture } \\
& \mathrm{R}^{2}=0.28 \\
& \mathrm{AA}=\text { sample acetic acid concentration }
\end{aligned}
$$

